Marquette University

e-Publications@Marquette

$10-2012$

\title{
Experimental Documentation of the Structural Consequences of Hydrogen-Bonding Interactions to the Proximal Cysteine of a Cytochrome P450
}

\author{
Piotr J. Mak \\ Marquette University, piotr.mak@marquette.edu \\ Yuting Yang \\ University of Michigan and VA Medical Center \\ Sangchoul Im \\ University of Michigan and VA Medical Center \\ Lucy A. Waskell \\ University of Michigan and VA Medical Center \\ James R. Kincaid \\ Marquette University, james.kincaid@marquette.edu
}

Follow this and additional works at: https://epublications.marquette.edu/chem_fac

Part of the Chemistry Commons

\section{Recommended Citation}

Mak, Piotr J.; Yang, Yuting; Im, Sangchoul; Waskell, Lucy A.; and Kincaid, James R., "Experimental Documentation of the Structural Consequences of Hydrogen-Bonding Interactions to the Proximal Cysteine of a Cytochrome P450" (2012). Chemistry Faculty Research and Publications. 402.

https://epublications.marquette.edu/chem_fac/402 


\title{
Experimental Documentation of the Structural Consequences of Hydrogen-Bonding Interactions to the Proximal Cysteine of a Cytochrome $\mathrm{P}_{45} \mathrm{O}^{* *}$
}

\author{
Piotr J. Mak \\ Department of Chemistry, Marquette University \\ Milwaukee, WI \\ Yuting Yang \\ Department of Anesthesiology, University of Michigan and VA \\ Medical Center \\ Ann Arbor, MI \\ Sangchoul Im \\ Department of Anesthesiology, University of Michigan and VA \\ Medical Center \\ Ann Arbor, MI \\ Lucy A. Waskell \\ Department of Anesthesiology, University of Michigan and VA \\ Medical Center \\ Ann Arbor, MI \\ James R. Kincaid \\ Department of Chemistry, Marquette University \\ Milwaukee, WI
}


NOT THE PUBLISHED VERSION; this is the author's final, peer-reviewed manuscript. The published version may be accessed by following the link in the citation at the bottom of the page.

\begin{abstract}
Resonance Raman spectroscopy is used to document, for the first time, a $6 \mathrm{~cm}^{-1}$ decrease of the Fe-S stretch by introducing an $\mathrm{H}$-bond donor into the proximal pocket of a cytochrome P450, which interacts with the key cysteine thiolate axial ligand. The anticipated trans-effect on bound exogenous ligands is also confirmed and evidence is obtained supporting intimate interaction of the new histidyl-imidazole fragment with the heme periphery.
\end{abstract}

Keywords: biophysics, heme proteins, oxidoreductases, Raman spectroscopy

Members of the widely distributed cytochrome P450 class of monoxygenases, or CYPs, generate highly reactive oxygen-derived intermediates that effect a diverse set of reactions, including hydroxylation and epoxidation of relatively inert substrates, ${ }^{[1-3]}$ thereby facilitating such important physiological functions as steroid biosynthesis and metabolism of pharmaceuticals. ${ }^{[4,5]}$ The active site heme $b$ is bound by a proximal cysteine thiolate, while on the distal side the heme is presented with an intricately arranged set of residues facilitating proton transfer to ferric peroxo- and ferric hydroperoxospecies. ${ }^{[6]}$ Substrate binding to the six coordinate, low-spin (6cLS) ferric resting state converts it to a five-coordinate, high-spin state $(5 \mathrm{cHS})$ that is reduced by natural redox partners, with the resulting ferrous form then binding dioxygen. Normally, the enzymatic cycle continues on to completion (oxidation of substrate) by accepting one more electron from a reductase to generate a peroxo-intermediate. Sequential delivery of two protons generates an initial hydroperoxointermediate and then the so-called Compound I, a potent oxidizing species generally formulated as a ferryl heme $n$-cation radical. ${ }^{[1-3,7]}$ Understandably, there is considerable interest in gaining insight into the structural factors that control the reactivity of the intermediates encountered within this cycle. ${ }^{\left[{ }^{8-10]}\right.}$ One obvious point of interest is that the strongly electron donating axial thiolate of all CYPs and structurally related enzymes, such as Nitric Oxide Synthases (NOSs), can promote $\mathrm{O}-\mathrm{O}$ bond cleavage or impact the behavior of subsequent intermediates. ${ }^{[11-15]}$ The effective negative charge on this proximal cysteine-thiolate could be fine-tuned by the nature and number of suitably positioned $\mathrm{H}$-bond donors known to be present in the proximal pocket ${ }^{[14-23]}$ A direct measure of the immediate consequences of such $\mathrm{H}$-bonding is documentation of the strength of the Fe-S linkage, a task most readily accomplished by resonance Raman (rR) spectroscopy, 
using excitation within the $\mathrm{S} \rightarrow$ Fe charge transfer transition envelope that occurs near $360 \mathrm{~nm}$ in the ferric HS form. ${ }^{[14,16-18,24-26]}$ In the present work this direct spectroscopic method is used to interrogate active site structural changes that accompany a single site mutation of a truncated form of CYP2B4; i.e., the F429H variant, where the highly conserved proximal-side phenylalanine is replaced with the potentially $\mathrm{H}$-bonding histidyl residue. The essential results obtained provide new definitive experimental evidence for the influence of proximal-side $\mathrm{H}$ bonding on the key Fe-S linkage and its effects on the cytochrome P450 cycle.

This $\mathrm{F} 429 \mathrm{H}$ mutant is of great interest, because the presence of this additional $\mathrm{H}$-bond drastically diminished the enzyme's ability to promote $\mathrm{O}-\mathrm{O}$ bond cleavage. ${ }^{\left[{ }^{9]}\right.}$ Additionally, computational studies have suggested that the mutant's heme oxygenase activity could arise as a result of a predicted weakening of the Fe-S bond strength. ${ }^{[15]}$ Figure 1 shows the Soret band-excited rR spectra obtained for the substrate-free (SF) and butylated hydroxytoluene (BHT)-bound "wild type" ferric CYP2B4 and its F429H mutant. In the case of the WT enzyme (traces $A$ and $B$ ), substrate binding causes an almost complete conversion from a $6 \mathrm{cLS}$ to $5 \mathrm{cHS}$ state; i.e. the $\mathrm{v}_{3}$ "spin-state marker" shifts from 1502 to $1487 \mathrm{~cm}^{-1 .[27-29]}$

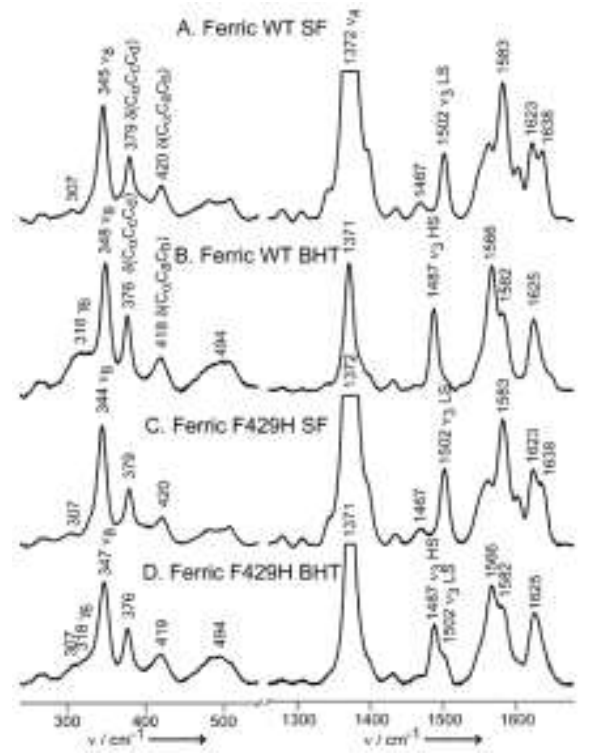

Figure 1 The low (left) and high (right) frequency rR spectra of ferric CYP2B4, wild-type substrate-free (A), wild-type BHT-bound (B), F429H mutant substrate-free

Angewandte Chemie International Edition, Vol. 51, No. 41 (October 2012): pg. 10403-10407. DOI. This article is (C) WileyVCH Verlag and permission has been granted for this version to appear in e-Publications@Marquette. Wiley-VCH Verlag does not grant permission for this article to be further copied/distributed or hosted elsewhere without the express permission from Wiley-VCH Verlag. 
(C) and $\mathrm{F} 429 \mathrm{H}$ mutant BHT-bound. Spectra measured with $406 \mathrm{~nm}$ excitation line and normalized to the $\mathrm{v} 3$ mode.

Similar behavior is documented for the $\mathrm{F} 429 \mathrm{H}$ mutant, though the conversion is not as complete. This residual $6 \mathrm{cLS}$ fraction seen for the mutant might arise from decreased affinity for the substrate or from a conformational heterogeneity that increases the stability of the aquo-bound form. However, the absence of the SF form for the CO adduct (vide infra) argues against the former case, unless one invokes a significantly different substrate affinity between the ferric and ferrous forms. In the low frequency region the bending modes associated with the propionate and vinyl substituents are observed near $\sim 370 \mathrm{~cm}^{-1}$ and $400-440 \mathrm{~cm}^{-1}$, respectively. In contrast to behavior seen for bacterial P450s, ${ }^{[16,30]}$ only small shifts are typically seen for microsomal mammalian CYPs such as those of interest here, ${ }^{[26,31]}$ whose distal pockets are larger and more flexible. ${ }^{[1,2]}$ It is noted, on the other hand, that BHT binding to both enzymes studied here does activate out-of-plane (oop) modes at 318 and $\sim 500 \mathrm{~cm}^{-1}$.

The key $v(\mathrm{Fe}-\mathrm{S})$ mode is enhanced only via excitation within the Fe-S charge transfer transition that occurs near $360 \mathrm{~nm}$ for the (substrate-bound) ferric HS state. ${ }^{[24]}$ Thus, in Figure 2 this mode is observed as a relatively strong feature appearing at $353 \mathrm{~cm}^{-1}$ in the BHT-bound WT enzyme and at $347 \mathrm{~cm}^{-1}$ for the BHT-bound CYP2B4 $\mathrm{F} 429 \mathrm{H}$. While the $347 \mathrm{~cm}^{-1}$ feature observed in the spectrum of the $\mathrm{F} 429 \mathrm{H}$ mutant is accidently degenerate with the $347 \mathrm{~cm}^{-1}$ feature seen in with Soret excitation (Figure 1, Trace D left), the two features correspond to two different modes; i.e., the $\mathrm{v}(\mathrm{Fe}-\mathrm{S})$ and the $\mathrm{v}_{8}$ modes, respectively. Convincing evidence for this is presented in the Supporting Information, where it is shown that the observed bandwidths are substantially broader for these $353 / 347 \mathrm{~cm}^{-1}$ features than those observed for the heme modes (Figure S2). 


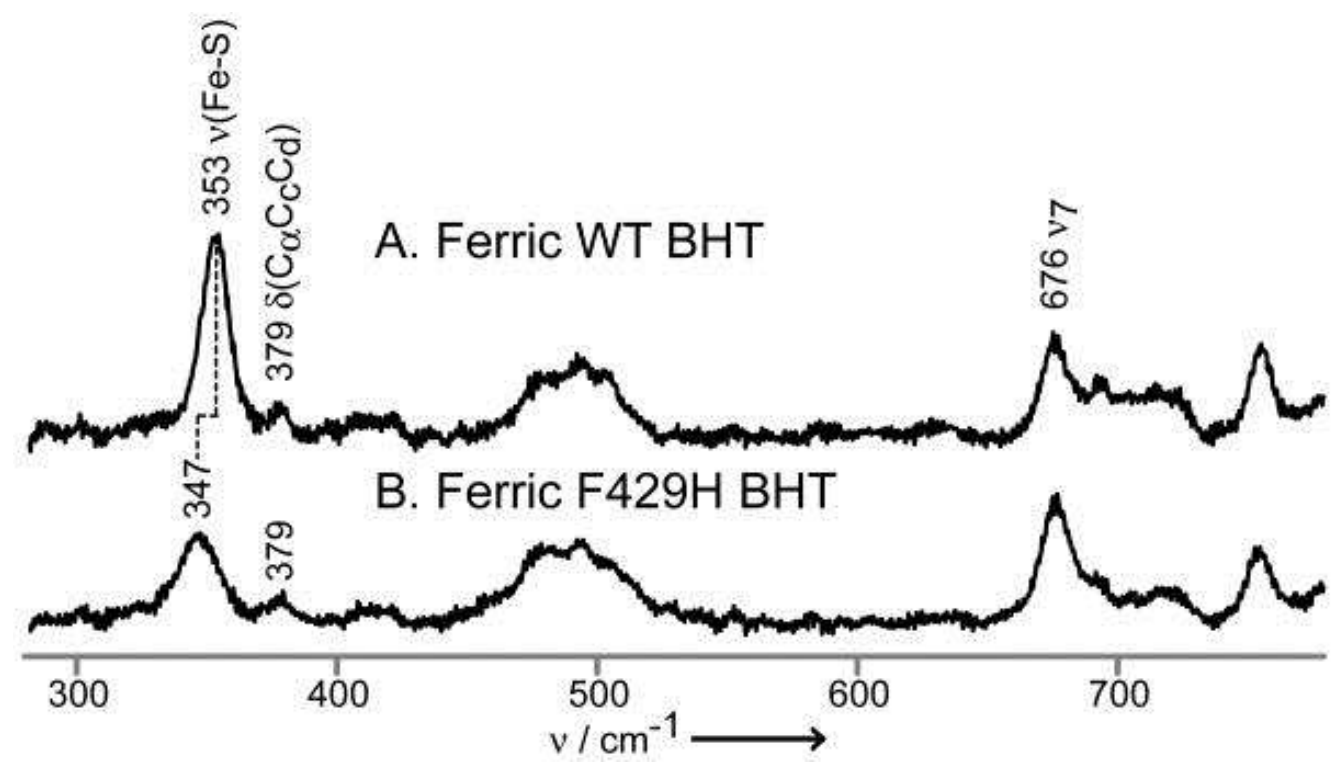

Figure 2 The low frequency rR spectra of ferric CYP2B4, wild-type BHT-bound (A) and $\mathrm{F} 429 \mathrm{H}$ mutant BHT-bound (B). Spectra measured with $356 \mathrm{~nm}$ excitation line and normalized to the $\mathrm{v}_{7}$ mode at $676 \mathrm{~cm}^{-1}$.

The observed $6 \mathrm{~cm}^{-1}$ shift of $\mathrm{v}(\mathrm{Fe}-\mathrm{S})$ to lower frequency for $\mathrm{F} 429 \mathrm{H}$ is qualitatively consistent with expectations based on the reduction of effective negative charge on the thiolate, in agreement with recent computations. ${ }^{[14,15]}$ Similar earlier rR work with CYP101 ${ }^{[17]}$ and CYP102, ${ }^{[16]}$ led to unexpected results; i.e., removal of existing $\mathrm{H}$ bond donors led either to no effect on the observed $v(\mathrm{Fe}-\mathrm{S})$ frequency or an unexpected decrease, ${ }^{[17]}$ while an attempt to introduce a new $\mathrm{H}$ bond donor residue to the proximal pocket of CYP102 (i.e., $\mathrm{F} 393 \mathrm{H}$ ) failed to induce any observable shift of its $v(\mathrm{Fe}-\mathrm{S})$ mode. ${ }^{[16]}$ The former result was later suggested to be attributable to vibrational mode reorganization. ${ }^{[14]}$ The absence of any changes on the $v(\mathrm{Fe}-\mathrm{S})$ mode for the $\mathrm{F} 393 \mathrm{H}$ mutant of CYP102 was interpreted as evidence that the histidyl residue was not in a proper orientation to $\mathrm{H}$-bond to the proximal cysteine thiolate fragment. ${ }^{[16,32]}$ Given these complications encountered in these previous $r R$ studies, it is satisfying that the present results agree with the predicted influence on the Fe-S bond strength. ${ }^{[14,15]}$

The new $\mathrm{H}$-bonding modulation of the Fe-S bond strength is also reflected in the altered electronic structure of the trans-axial Fe-C-O linkage of the ferrous $\mathrm{CO}$ adduct. Thus, as shown in Figure 3 (top), the $v(\mathrm{Fe}-\mathrm{C})$ shifts up by $3 \mathrm{~cm}^{-1}$ for the mutant (i.e., $463 \rightarrow 466$ and 473

Angewandte Chemie International Edition, Vol. 51, No. 41 (October 2012): pg. 10403-10407. DOI. This article is (C) WileyVCH Verlag and permission has been granted for this version to appear in e-Publications@Marquette. Wiley-VCH Verlag does not grant permission for this article to be further copied/distributed or hosted elsewhere without the express permission from Wiley-VCH Verlag. 
$\rightarrow 476 \mathrm{~cm}^{-1}$ for the SF and BHT-bound comparisons), with the $\mathrm{v}(\mathrm{C}-\mathrm{O})$ modes also shifting up by $5-7 \mathrm{~cm}^{-1}$ for the same comparisons (i.e., $1957 \rightarrow 1962$ and $\left.1945 \rightarrow 1952 \mathrm{~cm}^{-1}\right)$. These directly correlated shifts of the $\mathrm{v}(\mathrm{Fe}-\mathrm{C})$ and $\mathrm{v}(\mathrm{C}-\mathrm{O})$ modes, both to higher frequency, are indicative of a diminished $\sigma$-donation of the trans-axial proximal thiolate ligand resulting from the newly introduced $\mathrm{H}$-bonding histidine residue, such behavior being in agreement with predictions made from several high-level computational studies. ${ }^{[14,15,33]}$ It is noted that earlier computational work, supported with modest experimental data for models, has previously been used to argue this point for the isoelectronic ferric NO adducts. ${ }^{[34]}$

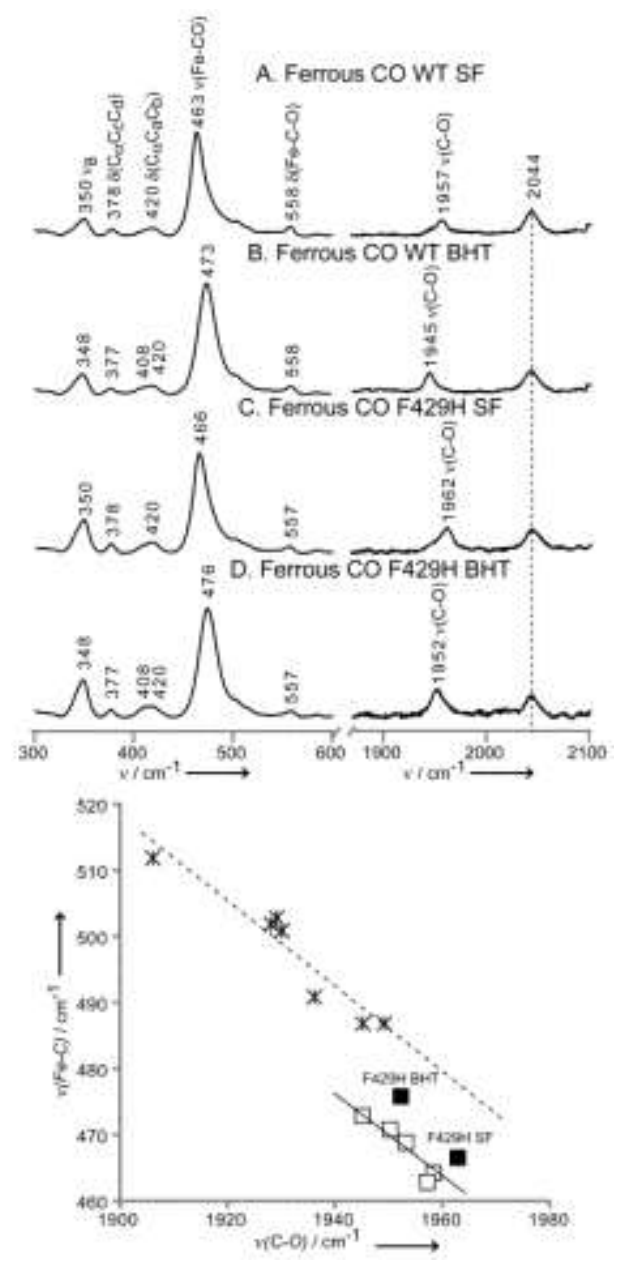

Figure 3 The low (left) and high (right) frequency rR spectra of ferrous $\mathrm{CO}$ adducts of CYP2B4, wild-type substrate-free (A), wild-type BHT-bound (B), F429H mutant substrate-free (C) and F429H mutant BHT-bound (D). Spectra measured with $442 \mathrm{~nm}$ excitation line and normalized to the $\mathrm{v} 7$ and $\mathrm{v} 4$ modes for low and high frequency region, respectively. The bottom graph shows linear correlation between $\mathrm{v}(\mathrm{Fe}-\mathrm{C})$ and

Angewandte Chemie International Edition, Vol. 51, No. 41 (October 2012): pg. 10403-10407. DOI. This article is @ WileyVCH Verlag and permission has been granted for this version to appear in e-Publications@Marquette. Wiley-VCH Verlag does not grant permission for this article to be further copied/distributed or hosted elsewhere without the express permission from Wiley-VCH Verlag. 
NOT THE PUBLISHED VERSION; this is the author's final, peer-reviewed manuscript. The published version may be accessed by following the link in the citation at the bottom of the page.

$\mathrm{V}(\mathrm{C}-\mathrm{O})$ frequencies, the open squares represent wild type truncated CYP2B4,[40] the solid squares indicate points for $\mathrm{F} 429 \mathrm{H}$ mutants and the stars show mammalian NOSs.[37-39]

Furthermore, the behavior seen here for the vibrational modes of the Fe-C-O fragment is satisfyingly consistent with data reported for $\mathrm{CO}$ adducts of NOS. ${ }^{[23]}$ Thus, the plots shown at the bottom of Figure 3 present data acquired for $\mathrm{CO}$ adducts of mammalian NOS (stars), the $\mathrm{CO}$ adducts of WT CYP2B4 under various conditions (open squares) and the two points obtained here for the F429H mutant of CYP2B4 (solid squares); additional data reported for bacterial NOS proteins, as well as the isoelectronic Fe(III)NO adducts of cytochromes P450 and model compounds, are given in Figure S3 of Supporting Information. The inverse correlations of the $\mathrm{v}(\mathrm{Fe}-\mathrm{C})$ and $\mathrm{v}(\mathrm{C}-\mathrm{O})$ modes are generally accepted to reliably reflect variations in polarity of the distal heme pocket, ${ }^{[33,35]}$ with displacements from one another along the vertical direction being the result of differences in the strength of the proximal ligand. Thus, the displacement of the NOS line from the CYP2B4 line arises because the Fe-S bonds of the NOSs are weakened by the presence of an $\mathrm{H}$-bond from a conserved tryptophan residue in the proximal pocket; i.e., their $\mathrm{v}(\mathrm{Fe}-\mathrm{S})$ stretching frequencies generally occur near $338 \mathrm{~cm}^{-1},{ }^{[36]}$ approximately $12-14 \mathrm{~cm}^{-1}$ lower than for cytochromes P450. As can be seen in Figure 3, the points derived for the $\mathrm{F} 429 \mathrm{H}$ mutant of CYP2B4 indeed are shifted towards the line for the NOS proteins, a shift entirely consistent with the observed $6 \mathrm{~cm}^{-1}$ lowering of the $\mathrm{v}(\mathrm{Fe}-\mathrm{S})$ for this mutant. [37-39]

Finally, it is noteworthy that the remarkable structural sensitivity of the $\mathrm{rR}$ technique reveals small, but clearly detectable, mutation-induced changes for particular heme modes of the $\mathrm{F} 429 \mathrm{H}$ mutant. A complex difference pattern (Figure 4, trace $\mathrm{C}$ ) is obtained when comparing the rR spectra for the SF forms of ferrous $\mathrm{CO}$ adducts of the WT and $\mathrm{F} 429 \mathrm{H}$ mutant. A similar difference plot obtained for the pair of BHT-bound forms is given in trace D. These data show that, while the mutation does not significantly change the basic heme structure, as reflected in the constancy of the core-sensitive $v_{3}$ and $v_{11}$ modes, changes are evident in the spectral region associated with the $\mathrm{v}(\mathrm{C}=\mathrm{C})$ modes of the peripheral vinyl groups. The most reasonable interpretation of these difference patterns is that the vinyl mode envelope is shifted to slightly higher frequency, behavior which is

Angewandte Chemie International Edition, Vol. 51, No. 41 (October 2012): pg. 10403-10407. DOI. This article is @ WileyVCH Verlag and permission has been granted for this version to appear in e-Publications@Marquette. Wiley-VCH Verlag does not grant permission for this article to be further copied/distributed or hosted elsewhere without the express permission from Wiley-VCH Verlag. 
consistent with out-of-plane displacement of the vinyl groups. [16] This displacement diminishes the conjugation of the vinyl groups with the heme macrocyle $n$-system, with the result that the $v_{2}$ core mode, associated with stretching of the $\mathrm{C}_{\beta}-\mathrm{C}_{\beta}$ bonds of the pyrrole ring to which the vinyls are attached, ${ }^{[28]}$ is also altered, experiencing an increased resonance enhancement. Significantly, all of these changes are observed for modes of molecular fragments localized at or near the 2- and/or 4-vinyl groups and are therefore entirely consistent with the proposed interaction of the newly introduced histidyl imidazole with the pyrrole A-ring, based on inspection of recently the acquired $x$-ray crystal structure of the mutant. [LAW, unpublished]

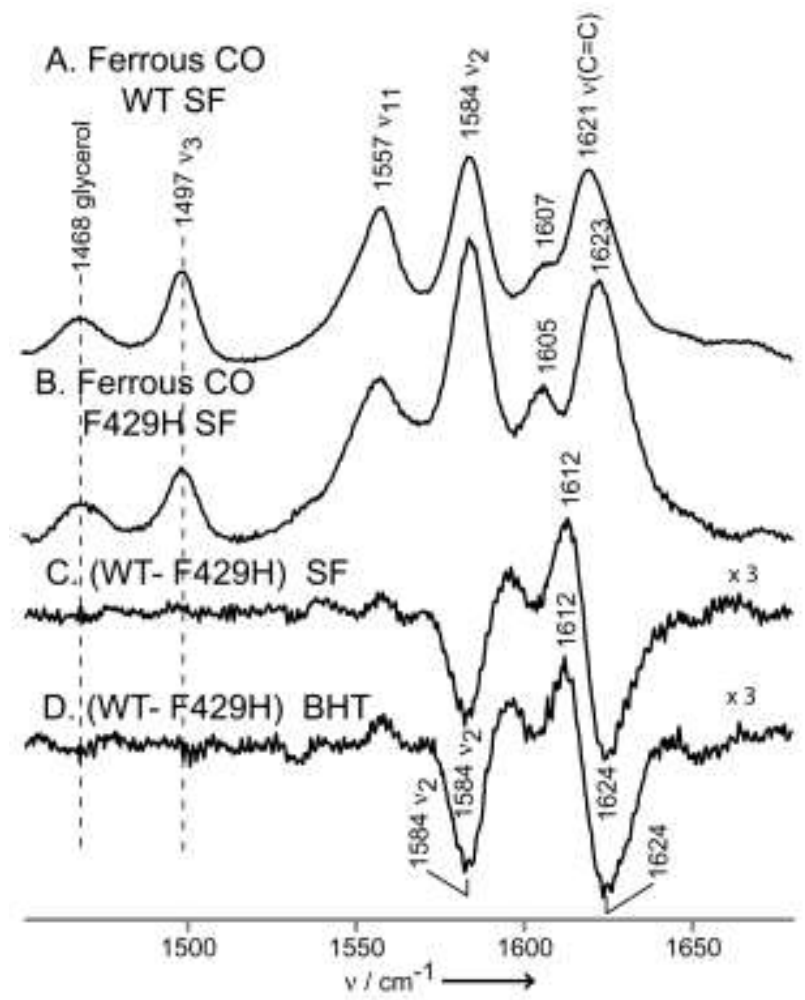

Figure 4 The high frequency $r R$ spectra of ferrous $C O$ adducts of substrate-free wild-type CYP2B4 (A) and F429H mutant (B). Spectra were normalized to the glycerol mode at $1468 \mathrm{~cm}-1$. The traces $(C)$ and $(D)$ are difference traces of ferrous $C O$ adducts of CYP2B4 wild-type and $429 \mathrm{H}$ mutant in substrate-free form (C) and in BHTbound state (D).

In summary, the present results show that the newly introduced $\mathrm{H}$-bond does indeed lead to a shift of the $\mathrm{v}(\mathrm{Fe}-\mathrm{S})$ stretching mode to lower frequency, documenting a weakening of this bond, as predicted

Angewandte Chemie International Edition, Vol. 51, No. 41 (October 2012): pg. 10403-10407. DOI. This article is @ WileyVCH Verlag and permission has been granted for this version to appear in e-Publications@Marquette. Wiley-VCH Verlag does not grant permission for this article to be further copied/distributed or hosted elsewhere without the express permission from Wiley-VCH Verlag. 
by theory. ${ }^{[14,15]}$ Furthermore, the impact of this modulation of Fe-S bond strength is transmitted to the heme iron linkage with a transaxial diatomic ligand ( $\mathrm{CO}$ ), as reflected in the observed behavior of the $\mathrm{v}(\mathrm{Fe}-\mathrm{C})$ and $\mathrm{v}(\mathrm{C}-\mathrm{O})$ modes of the Fe-C-O fragment, ${ }^{[23,41]}$ such electronic effects holding potential implications for functional properties. Finally, changes in certain heme vibrational modes provide convincing evidence for the presence of an intimate interaction between the replacement residue, $429 \mathrm{H}$, and the heme pyrrole A ring, a structural feature that is suggested from inspection of preliminary $X-$ ray crystallographic data. [LAW, unpublished]

\section{Experimental Section}

Plasmid for the truncated mutant was constructed from pLW01wild type full length P4502B4 plasmid. ${ }^{[42]}$ The cDNA coding for the 19 amino acids at the N-terminus (amino acids 3-21 of WT CYP2B4) were removed using NcoI restriction sites which had been inserted at position 3 and 21 by site directed mutagenesis. After removing the cDNA between the two NcoI sites, the remainder of the plasmid was religated by T4 DNA ligase (Invitrogen, NY). The following mutations, E2A, G22K, H23K, P24T, K25S, A26S, H27K, R29K, H226Y and F429H were then introduced into the $\triangle 3-21$ WT CYP2B4, using a QuikChange Site-Directed Mutagenesis Kit (Stratagene) to generate the $\mathrm{F} 429 \mathrm{H}$ mutant of the truncated form of CYP2B4. The truncated form of CYP2B4 (all of the mutations indicated above, minus the $\mathrm{F} 429 \mathrm{H}$ mutation), considered WT" above, is the form which had been previously engineered to allow successful crystallization when bound to different compounds. ${ }^{[43]}$

The plasmid pLW01 CYP450 2B4 F429H with cDNA for the mutant or WT CYP2B4 was transformed into C41 (DE3) cells. The cells were grown in TB medium at $23^{\circ} \mathrm{C}$ and induced with IPTG, supplemented with delta-aminolevulinic acid at induction and ethanol thirty minutes after induction. The induced cell culture was harvested $\sim 120 \mathrm{hr}$ after induction.

The protein samples were isolated and purified as previously described. ${ }^{[44]}$ Butylated hydroxytoluene (BHT) was added to all buffers to prevent conversion to cytochrome P420 during purification. The protein was eluted from hydroxyapatite column using buffer containing

Angewandte Chemie International Edition, Vol. 51, No. 41 (October 2012): pg. 10403-10407. DOI. This article is (C) WileyVCH Verlag and permission has been granted for this version to appear in e-Publications@Marquette. Wiley-VCH Verlag does not grant permission for this article to be further copied/distributed or hosted elsewhere without the express permission from Wiley-VCH Verlag. 
NOT THE PUBLISHED VERSION; this is the author's final, peer-reviewed manuscript. The published version may be accessed by following the link in the citation at the bottom of the page.

$0.4 \mathrm{M} \mathrm{K}_{2} \mathrm{HPO}_{4} / \mathrm{KH}_{2} \mathrm{PO}_{4} \mathrm{pH} 7.4$ and $20 \%$ glycerol. The purified protein was diluted into a final buffer containing $20 \%$ glycerol and $0.1 \mathrm{M}$ $\mathrm{K}_{2} \mathrm{HPO}_{4} / \mathrm{KH}_{2} \mathrm{PO}_{4} \mathrm{pH} 7.4$ and concentrated to $1 \mathrm{mM}$ using 50,000 MWCO VivaSpin 20.

\section{The rR measurements}

All samples are $\sim 0.4 \mathrm{mM}$ in heme. All further details, including solution conditions and spectrometer parameters are given in Supporting Information.

\section{Supplementary Material}

\section{Supporting Information}

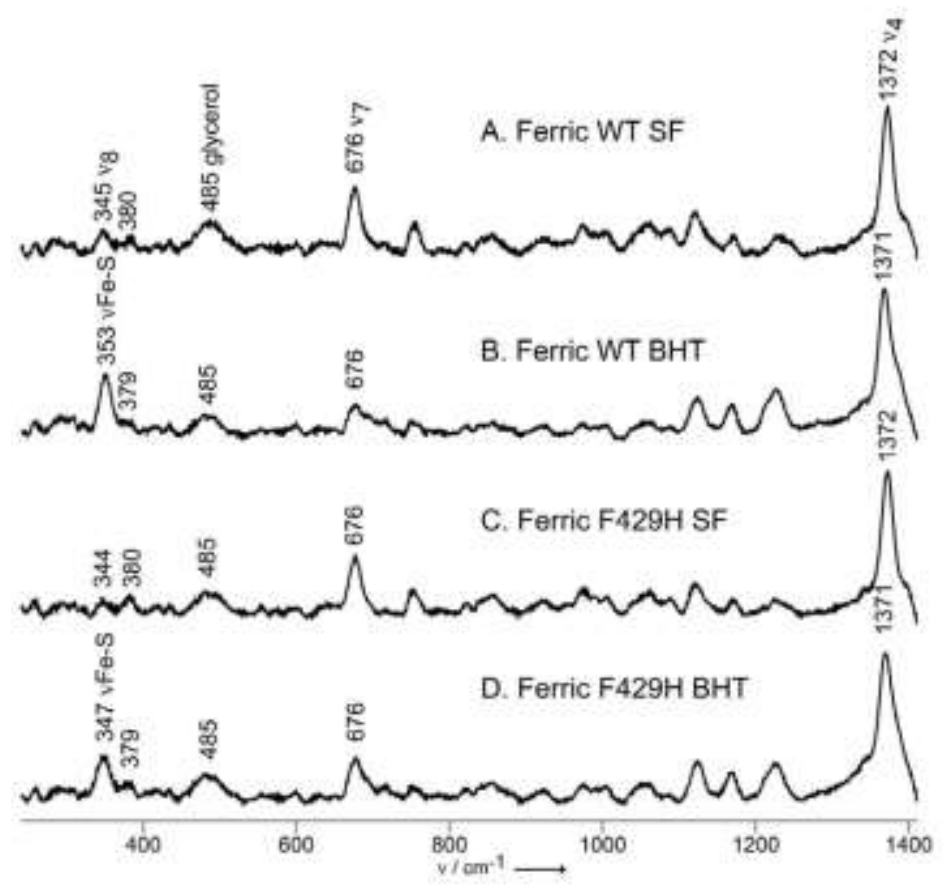

Figure S1. The RF spectra of ferric CYP2B 4, wid-type substrate-free (A), whid-type BHT-bound (B). F429H imutant substrate-tree (C) and $\mathrm{F} 429 \mathrm{H}$ mutant BHT-bound. Spectra measured with $356.4 \mathrm{~nm}$ excitation ine and normalized to the $\mathrm{V}_{4}$ mode.

Angewandte Chemie International Edition, Vol. 51, No. 41 (October 2012): pg. 10403-10407. DOI. This article is (c) WileyVCH Verlag and permission has been granted for this version to appear in e-Publications@Marquette. Wiley-VCH Verlag does not grant permission for this article to be further copied/distributed or hosted elsewhere without the express permission from Wiley-VCH Verlag. 
NOT THE PUBLISHED VERSION; this is the author's final, peer-reviewed manuscript. The published version may be accessed by following the link in the citation at the bottom of the page.

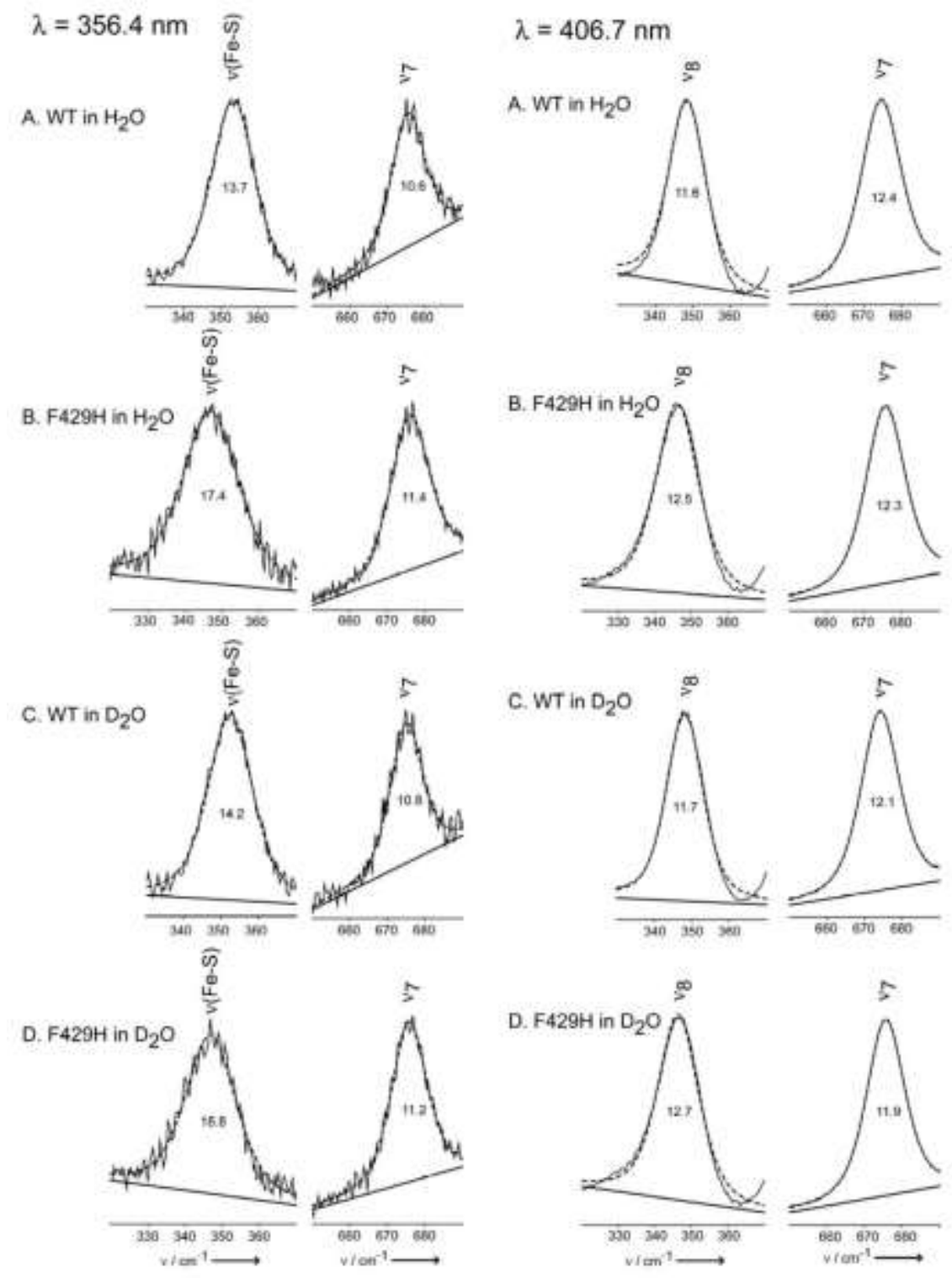

Figure S2. Deconvolution of the V(Fe-S), the $\mathrm{v}_{7}$ and the $\mathrm{v}_{1}$ bands of the ferric CYP2B4 BHT-bound spectra of wild type (WT) in $H_{3}$.O buffer

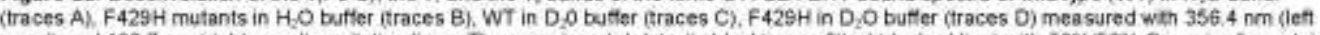
panei) and $406.7 \mathrm{~nm}$ (right panel) exctation lines. The experimental data (in black) were fitted (dashed line) with 50\%5036 Gaussian/Lorentzian functions. The numbers at $\mathrm{Y}$, haif of the peaks indicate their bendwid.hs. It is noted that the experiments in $\mathrm{D}, \mathrm{O}$ were performed in order to investigate the (admittedy unlikely) possibility thet change to deuterated medum might leed to slight frequency shifts. Though none were seen, the data is included here. since they provide addtional evidence for selective broadening of the w(Fe-Si modes.

Angewandte Chemie International Edition, Vol. 51, No. 41 (October 2012): pg. 10403-10407. DOI. This article is (C) WileyVCH Verlag and permission has been granted for this version to appear in e-Publications@Marquette. Wiley-VCH Verlag does not grant permission for this article to be further copied/distributed or hosted elsewhere without the express permission from Wiley-VCH Verlag. 
NOT THE PUBLISHED VERSION; this is the author's final, peer-reviewed manuscript. The published version may be accessed by following the link in the citation at the bottom of the page.

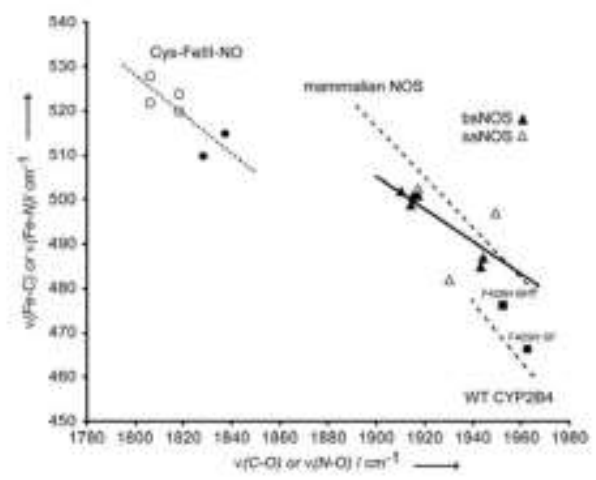

Figure S3. Linear correlation between W(Fe-C) $\propto$ w w F $-N$ ) and $w(C-O)$ or v(N-O) frequencies. The dashed lines represent the w(Fe-CMu(C-O) correlation lines (from Figure 3 of main text) for wild type CYP284 and mammalian NOSs. mutant of P4502B4. The trangles represent the points for bsNOS and saNOS and the sold ihe represents the WFe-CWV(C-O) linear correlation for those two sets of bacterial NOSs. In In the let upper cornes are shown points for thiolate ferric NO adducts of P450cam (o) and model compounds (*) and their correlation ine (dotted line).

\section{Experimental Section}

Preparation of samples for $\mathrm{r} R$ measurements: The truncated wid type 284 and $\mathrm{F} 429 \mathrm{H}$ mutant samples for r $R$ measuremens were in 100 mM phosphate buffer pH 7.4 containing 100-fold molar excess of BHT relative to protoin, $1 \mathrm{mM}$ dlauroylphosphatioyichoine (DL PC), $0.3 \mathrm{M} \mathrm{NaCl}$ and $20 \%$ of glycerol ideuterated dycerol for samples in $\mathrm{D}_{2} \mathrm{O}$ buffer). Final protein concentration was $-0.4 \mathrm{mM}$ in heme: The ferrous CO adducts were prepared by saturating the ferric samples enclosed in $5 \mathrm{~mm}$ NMR tubes with $C O$ gas and reducing them with $\sim 2$ molar. equivalents of sodium dithionite solution.

The rR measurements. The ferric samples were measured using the $405.7 \mathrm{~nm}$ and $358.4 \mathrm{~nm}$ excitation ines from a $\mathrm{Kr}^{\circ}$ laser iCoherent innova Sabre ion Laser) and the Feil)-CO adducts were excited by $441.6 \mathrm{~nm}$ line prowided by a He-Cd laser (IK Series He-Cd laser, Kimmon Koha CO. LTD.). The RR spectra of al samples were measured using a Spex 1269 spectrometer equipped with an Andor Newton ENACCD detecter (Model DU971. Andor Technologies). The slit wicth was set at 150 um and the 1200 or $2400 \mathrm{~g} / \mathrm{mm}$ grating were used. The laser power at the ferric sample was aqusted to $-10 \mathrm{~mW}$ while for ferrous $C O$ adducts was kept at $-1 \mathrm{miN}$. Spectra were calibrated with fenchone iSigma-Aidrich. Wi. toluene-Ds and acetone-Div (Cambridge isctope Laboratories. Inc. MA) and processed with Grams/32 Al sotiware (Galactic industries. Salem, NH).

\section{References}

[S1] A, Brunel, A. Wilsce, L. Henry, P. Dorlet, J, Santolini, J. Bich. Chem, 2011, 256, 11997-12005

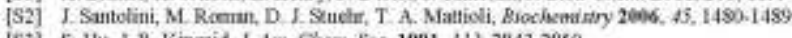

[S3] 5. Hik, I. R. Kincsid $J$, Am Chem. Sor. 1991, $113,2843-2850$.

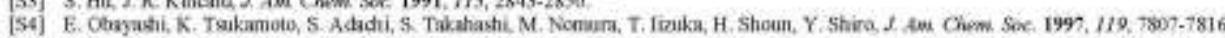

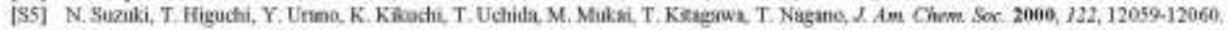

\section{Footnotes}

${ }^{* *}$ This work was supported in part by National Institutes of Health grants R01GM096117 (to JRK) from the National Institutes of General Medical Sciences and National Institutes of Health grants R01GM035533 and R01GM094209 and VA Merit Review Grant (to LAW).

Supporting information for this article is available on the WWW under http://www.angewandte.org or from the author.

\section{Contributor Information}

Dr. Piotr J. Mak, Department of Chemistry, Marquette University, Milwaukee, WI 53233 (USA), Fax: 4142887066.

Angewandte Chemie International Edition, Vol. 51, No. 41 (October 2012): pg. 10403-10407. DOI. This article is (C) WileyVCH Verlag and permission has been granted for this version to appear in e-Publications@Marquette. Wiley-VCH Verlag does not grant permission for this article to be further copied/distributed or hosted elsewhere without the express permission from Wiley-VCH Verlag. 
NOT THE PUBLISHED VERSION; this is the author's final, peer-reviewed manuscript. The published version may be accessed by following the link in the citation at the bottom of the page.

Dr. Yuting Yang, Department of Anesthesiology, University of Michigan and VA Medical Center, Ann Arbor, MI 48105 (USA), Fax: 7348453096.

Dr. Sangchoul Im, Department of Anesthesiology, University of Michigan and VA Medical Center, Ann Arbor, MI 48105 (USA), Fax: 7348453096.

Prof. Lucy A. Waskell, Department of Anesthesiology, University of Michigan and VA Medical Center, Ann Arbor, MI 48105 (USA), Fax: 7348453096.

Prof. James R. Kincaid, Department of Chemistry, Marquette University, Milwaukee, WI 53233 (USA), Fax: 4142887066.

\section{References}

1. Ortiz de Montellano PR, editor. Cytochrome P450: Structure, Mechanism and Biochemistry. 3. Kluwer/Plenum; New York: 2004.

2. Sigel A, Sigel H, Sigel RKO, editors. Metal Ions in Life Sciences. Vol. 3. John Wiley \& Sons, Ltd; Chichester: 2007.

3. Coon MJ. Ann Rev Pharmacol Toxicol. 2005;45:1-25

4. Guengerich FP. Chem Res Toxicol. 2008;21:70-83.

5. Hollenberg PF, Kent UM, Bumpus NN. Chem Res Toxicol. 2008;21:189205.

6. Denisov IG, Makris TM, Sligar SG, Schlichting I. Chem Rev. 2005;105:2253-2277.

7. Terner J, Palaniappan V, Gold A, Weiss R, Fitzgerald MM, Sullivan AM, Hosten CM. J Inorg Biochem. 2006;100:480-501.

8. Davydov R, Macdonald IDG, Makris TM, Sligar SG, Hoffman BM. J Am Chem Soc. 1999;121:10654-10655.

9. Davydov R, Razeghifard R, Im SC, Waskell L, Hoffman BM. Biochemistry. 2008;47:9661-9666.

10. Denisov IG, Mak PJ, Makris TM, Sligar SG, Kincaid JR. J Phys Chem A. 2008; 112:13172-13179.

11. Rittle J, Green mT. Science. 2010;330:933-937.

12. Shaik S, Cohen S, Wang Y, Chen H, Kumar D, Thiel W. Chem Rev. 2010;110:949-1017.

13. Stone KL, Behan RK, Green MT. Proc Natl Acad Sci USA. 2006;103:12307-12310.

14. Galinato MGI, Spolitak T, Ballou DP, Lehnert N. Biochemistry. 2011;50:1053-1069.

15. Usharani D, Zazza C, Lai W, Chourasia M, Waskell L, Shaik S. J Am Chem Soc. 2012;134:4053-4056.

16. Chen Z, Ost TWB, Schelvis JPM. Biochemistry. 2004;43:1798-1808.

Angewandte Chemie International Edition, Vol. 51, No. 41 (October 2012): pg. 10403-10407. DOI. This article is (c) WileyVCH Verlag and permission has been granted for this version to appear in e-Publications@Marquette. Wiley-VCH Verlag does not grant permission for this article to be further copied/distributed or hosted elsewhere without the express permission from Wiley-VCH Verlag. 
NOT THE PUBLISHED VERSION; this is the author's final, peer-reviewed manuscript. The published version may be

accessed by following the link in the citation at the bottom of the page.

17. Yoshioka S, Tosha T, Takahashi S, Ishimori K, Hori H, Morishima I. J Am Chem Soc. 2002;124:14571-14579.

18. Lang J, Santolini J, Couture M. Biochemistry. 2011;50:10069-10081.

19. Ogliaro F, Cohen S, de Visser SP, Shaik S. J Am Chem Soc. $2000 ; 122: 12892-12893$.

20. Ogliaro F, de Visser SP, Shaik S. J Inorg Biochem. 2002;91:554-567.

21. Poulos TL, Finzel BC, Howard AJ. J Mol Biol. 1987;195:687-700.

22. Ravichandran KG, Boddupalli SS, Hasemann CA, Peterson J, Deisenhofer J. Science. 1993;261:731-736.

23. Hasemann CA, Ravichandran KG, Boddupalli SS, Peterson J, Deisenhofer J. Structure. 1995;3:41-62.

24. Champion PM, Stallard BR, Wagner GC, Gunsalus IC. J Am Chem Soc. 1982;104:5469-5472.

25. Sabat J, Stuehr DJ, Yeh SR, Rousseau DL. J Am Chem Soc. 2009;131:12186-12192.

26. Mak PJ, Im SC, Zhang H, Waskell LA, Kincaid JR. Biochemistry. 2008;47:3950-3963.

27. Kitagawa T, Mizutani Y. Coord Chem Rev. 1994;135/136:685-735.

28. Spiro TG, editor. Biological Applications of Raman Spectroscopy. III. John Wiley and Sons; New York: 1988.

29. Kincaid JR. In: Porphyrin Handbook. Kadish KM, Smith KM, Guilard R, editors. Vol. 7. Academic Press; San Diego: 2000. pp. 225-291.

30. Mak PJ, Kaluka D, Manyumwa EM, Zhang H, Deng T, Kincaid JR. Biopolymers. 2008;89:1045-1053.

31. Mak PJ, Denisov IG, Grinkova YV, Sligar SG, Kincaid JR. J Am Chem Soc. 2011;133:1357-1366.

32. Ost TWB, Munro AW, Mowat CG, Taylor PR, Pesseguiero A, Fulco AJ, Cho AK, Cheesman MA, Walkinshaw MD, Chapman SK. Biochemistry. 2001;40:13430-13438.

33. Xu C, Ibrahim M, Spiro TG. Biochemistry. 2008;47:2379-2387.

34. Paulat F, Lehnert N. Inorg Chem. 2007;46:1547-1549.

35. Li XY, Spiro TG. J Am Chem Soc. 1988;110:6024-6033.

36. Schelvis JPM, Berka V, Babcock GT, Tsai A. Biochemistry. 2002;41:56955701.

37. Wang J, Stuehr DJ, Ikeda-Saito M, Rousseau DL. J Biol Chem. $1993 ; 268: 22255-22258$.

38. Fan B, Wang J, Stuehr DJ, Rousseau DL. Biochemistry. 1997;36:1266012665.

39. Wang J, Stuehr DJ, Rousseau DL. Biochemistry. 1997;36:4595-4606.

40. Mak PJ, Zhang H, Hollenberg PF, Kincaid JR. J Am Chem Soc. 2010;132:1494-1495.

41. Spiro TG, Wasbotten IH. J Inorg Biochem. 2005;99:34-44.

Angewandte Chemie International Edition, Vol. 51, No. 41 (October 2012): pg. 10403-10407. DOI. This article is (C) WileyVCH Verlag and permission has been granted for this version to appear in e-Publications@Marquette. Wiley-VCH Verlag does not grant permission for this article to be further copied/distributed or hosted elsewhere without the express permission from Wiley-VCH Verlag. 
NOT THE PUBLISHED VERSION; this is the author's final, peer-reviewed manuscript. The published version may be accessed by following the link in the citation at the bottom of the page.

42. Bridges A, Gruenke L, Chang YT, Vakser IA, Lowe G, Waskell L. J Biol Chem. 1998;273:17036-17049.

43. Scott EE, White MA, He YA, Johnson EF, Stout CD, Halpert JR. J Biol Chem. 2004;279:27294-27301.

44. Saribas AS, Gruenke L, Waskell L. Protein Express Purif. 2001;21:303309.

Angewandte Chemie International Edition, Vol. 51, No. 41 (October 2012): pg. 10403-10407. DOI. This article is (C) WileyVCH Verlag and permission has been granted for this version to appear in e-Publications@Marquette. Wiley-VCH Verlag does not grant permission for this article to be further copied/distributed or hosted elsewhere without the express permission from Wiley-VCH Verlag. 